\title{
Az edzés pihenöidejében alkalmazott okklúzió hatása négyhetes guggoló edzést végzó egyének átlagsebesség mutatóira
}

\section{The effect of resting period occlusion on average velocity characteristics during 4 weeks of squat exercise protocol}

\author{
Torma Ferenc, Gombos Zoltán, Bakonyi Péter, Radák Zsolt
}

Testnevelési Egyetem, Molekuláris Edzésélettani Kutató Központ

\begin{abstract}
Absztrakt - Az okklúziós edzés egy olyan edzésforma, mely a végtagra felhelyezett elszorító eszközzel korlátozza a mozgást végző izom vénás visszaáramlását. Jelen vizsgálatunkban 20 fizikailag aktív egészséges fiatal felnótt végzett 4 hetes guggoló gyakorlatos edzésprogramot. Az edzési időszakban a résztvevók a maximális egyismétléses maximumuk $70 \%$-val edzettek, mely a sportéletben is széles körben alkalmazott vázizom hipertrófizáló edzésforma. Vizsgálatunkban a kontroll csoport alanyai $(n=10) 1$ hónapig hetente 3-szor, 5-ször 10 ismétlést hajtottak végre edzésenként 2 perces szettek közötti pihenóvel. Az okklúziós csoport $(n=10)$ hasonló edzéskarakterisztikákkal dolgozott, annyi különbséggel, hogy a vizsgálati személyek a szettek közötti pihenó idóben 1 perces mandzsettás okklúzióban részesültek az alsó végtagon. A munkavégzés intenzitását az ismétlések átlagsebesség változóival jellemeztük. Eredményeink szerint az általunk alkalmazott okklúziós edzés nem befolyásolta számottevóen az alanyok átlagos sebesség paraméterit az edzés protokoll ideje alatt, habár eltérő adaptációs folyamatok feltételezhetők.
\end{abstract}

Kulcsszavak: okklúziós edzés, guggoló edzés, átlagsebesség

\begin{abstract}
The occlusion training is a training method based on the blood flow restriction of the exercising muscle. In the present study 4 weeks of squat exercise training was conducted by 10 healthy, physically active adult male individuals. During the exercise program the participants trained with the $70 \%$ of their one repetition maximum, applied in sport for skeletal muscle hypertrophy. The control group $(n=10)$ completed 5 sets of 10 repetitions with 2 minutes resting periods between sets, while the occlusion group $(n=10)$ is exposed to a occlusion cuff blood flow restriction for 1 min in the resting period between each sets. As a training characteristic the average velocity of the moved load was recorded. According to our result the occlusion treatment not affected significantly the improvement of the average velocity parameters during the training period. However different adaptation patterns are suspected.
\end{abstract}

Keywords: occlusion training, squat exercise, average velocity

\section{Bevezetés}

Az okklúziós edzésterhelés az edzést végző végtag vénás visszaáramlásának gátlásával történő edzés, mely alkalmazható az egész edzésmunka ideje alatt, de az effektív munkavégzéstől független időszakokban is, a pihenő időben, de akár a versenyek elötti prekondicionálási időszakban is (Scott és mtsai. 2016). Az okklúziós edzés néhány évtizeddel ezelőtt kavarta fel a sporttudományt, hiszen az addig hatástalannak vélt ingerrel, az egyismétléses koncentrikus izomfeszülés 20-30 százalékával, végzett edzés is a célizom hipertrófiáját eredményezte (Manimmanakorn és mtsai. 2013; Luebbers és mtsai. 2014; Yamanaka és mtsai. 2012). Ez a tény pedig némiképp ellent mondott annak az általánosan elfogadott nézetnek, mely szerint szignifikáns vázizom hipertrófiát csak a szövetben létrejövő mikrotraumák képesek kiváltani. 
A legelterjedtebb okklúziós edzésforma, az edzés ideje alatt végig alkalmazott, a vénás visszaáramlást korlátozó edzésmódszer. A módszer hátránya, hogy az élsportban a magas izomfeszüléssel végzett gyakorlatok preferálandóak, hiszen ezek eredményeznek optimális funkciófejlődést (American College of Sports Medicine 2009). A magas terhelési szinten edző vázizom anyagcseréje fokozott mértékű és ebben az esetben a kontrakció alatt alkalmazott okklúzió gátolhatja a myofibrillumok metabolikus folyamatait, ami problémás lehet (Wernbom, Augustsson és Raastad 2008). Az esetleges káros hatások elkerülése érdekében az erőkifejtést az egyismétléses maximum (1RM) 30\%-ban maximalizálják az ajánlások (Abe és mtsai. 2006), ha az elszorítást az edzés teljes ideje alatt kívánják alkalmazni. Az okklúziós módszert japán kutatók sikeresen alkalmazták a rehabilitáció területén, azonban a sportéletben a módszer kevésbé terjedt el, az említett alacsony terhelési szint miatt. Figyelemre méltó viszont, hogy ezzel a terheléssel is izomkeresztmetszet növekedés érhető el, ám alkalmazása az alacsony izomfeszülés miatt főként a rehabilitáció vagy a regeneráció területén javasolták a publikációk. (Yasuda és mtsai. 2014, Loenneke és mtsai. 2013)

Az kompetitív sportban optimális hipertrófizáló edzésnek 1RM 70\%-val történő terhelés tekinthető (American College of Sports Medicine position stand. 2019). Vizsgálatukban egy olyan új módszert teszteltük, mely a klasszikus okklúziós módszer és magas intenzitású rezisztencia edzés előnyeit kívánja ötvözni.

Edzésmódszerünk érdekes aspektusa, hogy az okklúziós edzések során a résztvevők az edzés pihenőidejében, a szettek közötti időintervallumokban részesültek 1 percnyi okklúzióban. Az ilyen jellegü terhelés előnye, hogy az edzés karakterisztikái lehetővé teszik a magasabb, az 1RM 70\%-val történő erőkifejtést, mely a gyors izomrostok bekapcsolódását is elösegítheti a munkavégzés közben. A kondicionális képességek és az élsport szempontjából a gyors motoros egységek bekapcsolása kulcsfontosságú az izomteljesítmény leadásának szempontjából. Vizsgálatunk során azt a kérdést tettük fel, hogy az alsó végtagon a pihenő időben alkalmazott okklúzió, mennyiben befolyásolja az „optimális intenzitásư" edzések során a vizsgálati alanyok munkavégzésének átlagsebességét, mely közvetlen összefüggést mutat az edzésteljesítménnyel.

\section{Anyag és módszer}

A kutatásban 10-10 önkéntes, egészséges, fiatal felnőtt férfi vett részt a Testnevelési Egyetem hallgatói közül. Az alanyok írásban nyilatkoztak, hogy önkéntesen vesznek részt az edzéseken és azt bármikor indoklás nélkül félbeszakíthatják és ez nem jár számukra semmilyen negatív következménynyel. Az edzésidőszak megkezdése előtt az alanyok sportorvosi kérdőívet töltöttek ki és nyilatkoztak, hogy nem szenvednek keringési, vaszkuláris, ortopédiás és egyéb olyan betegségben mely kockázati tényezőt jelent az edzések folyamán. Továbbá nyilatkoztak, hogy minden kérdésükre választ kaptak, megértették a vizsgálat célját és hozzájárulnak adataik tudományos célú felhasználásához. A vizsgálatot az ET-KEB/No8/2017 határozat engedélyezte.

Az edzési periódus előtt a "National Strength and Conditioning Association" által elfogadott módszerrel becsültük az alanyok 1 ismétléses maximumát. A résztvevők 20 perc szobakerékpáros bemelegítés és mobilizációs gyakorlatok után 3-4 próbálkozásból érték el a 3 ismétléses maximumukat. A próbálkozások között minimum 3, de maximum 5 perc pihenőidő állt az alanyok rendelkezésér. A munka súlyt a résztvevők háromismétléses maximum eredményeiből számoltuk ki Richens és Cleather közleménye alapján (Richens és Cleather 2014). Az edzési időszakban az önkéntesekből random módon két csoportot képeztünk egy okklúziós $(\mathrm{O}, \mathrm{n}=10)$ és egy kontrol csoportot $(\mathrm{K}, \mathrm{n}=10$ fó), (az alanyok lényegesebb jellemzőit az 1 . táblázat foglalja össze).

A kontrol csoport tagjai heti 3 alkalommal végeztek edzéseket. 1 x10 ismétlésszámú guggolást az 1 RM 30\%-val-, 1x10 ismétlésszámúot az $1 \mathrm{RM}$ $50 \%$-val, végül $5 \times 10$ ismétlésszámot az $1 \mathrm{RM}$ $70 \%$-val. A szettek közötti összesen 2 percnyi pihenőidőt stopperórával mértük.

Esetünkben az okklúziós csoport a kontrol csoporttal megegyező terhelést kapott, annyi eltéréssel, hogy két lábuk a szettek közötti pihenő időkben 1 percnyi okklúziónak volt kitéve. A mandzsetta (Mizuho Japán) nyomását az irodalomban is szereplö, biztonsággal alkalmazott 220-230 Hgmmben határoztuk meg (Loenneke és mtsai. 2012). A sorozatok közti pihenőidőt mind a két csoport féligfekvő helyzteben töltötte $45^{\circ}$ dőlésszögü padon. A vizsgálat kivitelezési sémáját és az okklúzió során készült reprezentatív popliteális ultrahangos felvétel az 1. ábrán látható. 
1. táblázat A vizsgálatban résztvevő alanyok alapvető antropometriai és életkor adatai (O. okklúziós csoport, K. kontroll csoport)

\begin{tabular}{|c|c|c|c|}
\hline & Test Magasság $[\mathbf{c m}]$ & Test Tömeg $[\mathrm{kg}]$ & Kor [év] \\
\hline O. Átlag & 183,1 & 80,6 & 23 \\
\hline O. Szórás & 8,3 & 5,8 & 2 \\
\hline K. Átlag & 183,3 & 76,1 & 24 \\
\hline K. Szórás & 7,2 & 9,3 & 2 \\
\hline
\end{tabular}

\section{$\mathbf{A}$}

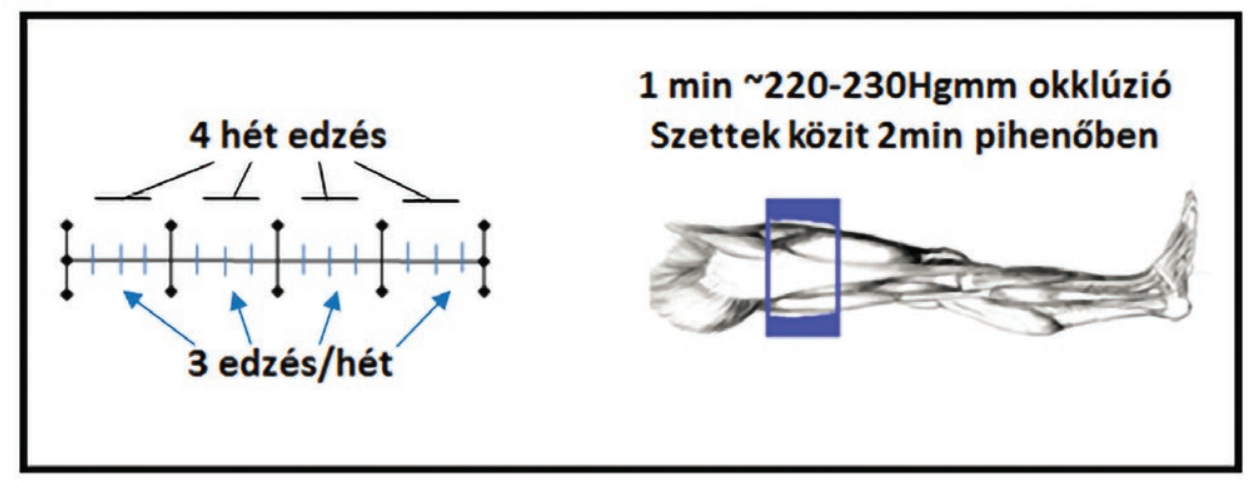

B

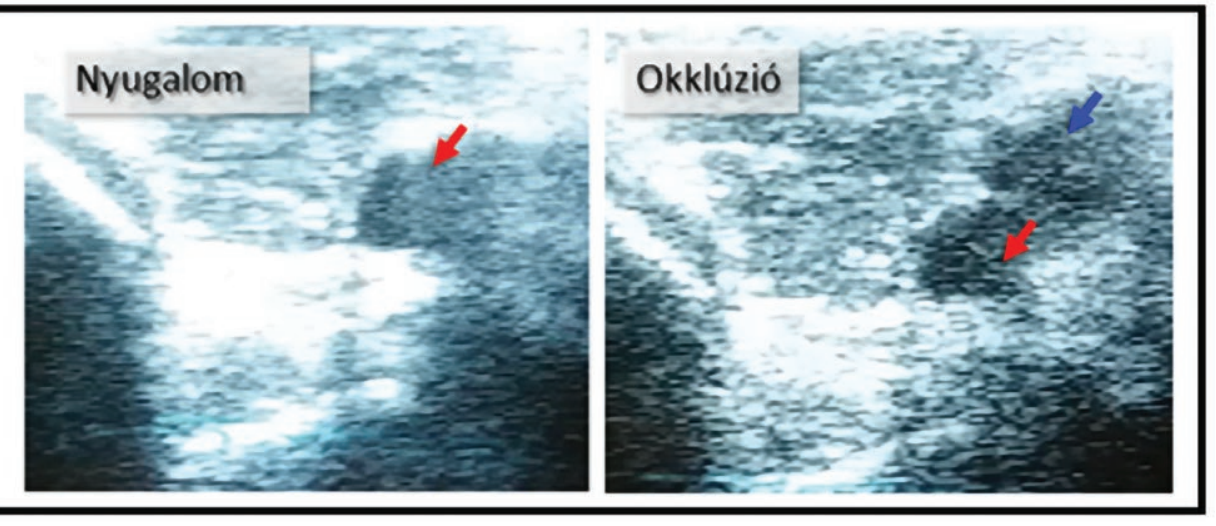

1. ábra A vizsgálati séma és reprezentatív ultrahang felvételek $A$ ábra: az edzés sematikus ábrázolása és az okklúziós mandzsetta felhelyezésének sémája. B ábra: az okklúzió során a popiteális area keresztmetszeti ultrahangos felvétele látható nyugalmi, illetve okklúziós állapotban. Piros nyíl: popliteális artéria, kék nyíl popliteális véna. Látható, hogy okklúzió alatt a véna és kismértékben az artéria is megduzzad.

A guggoló edzések során az alanyok azt az utasítást kapták, hogy törekedjenek a tőlük telhető legdinamikusabb kivitelezésre. A guggoló gyakorlatokat két vizsgálatvezető felügyelte, egyikük a helyes kivitelezésről (az alany a talajjal vízszintes helyzetig hajlítsa), másikuk a vizsgálati személy biztonságos gyakorlat végrehajtásáról gondoskodott. Az alanyok mindeközben verbális bíztatásban is részesültek.
$\mathrm{Az}$ ismétlések átlagsebesség értékeit linear encoderes eljárással rögzítettük (MuscleLab Power, Ergotest, Norvégia). A guggoló gyakorlatot a vizsgálati alanyok kötöttpályás guggoló kereten végezték. A gyakorlatok során az 5x10 1RM 70\%-os ismétlések függőleges lineáris pályán mozgó ellenállás átlagsebességét rögzítettük. A mért változónak az ismétlések áltagos sebességét választottuk, hiszen ez jobb összehasonlítási alapul szolgál az alanyok 
között, mivel ebből a változóból hiányzik a tömeg komponens, mégis erősen korrelál a leadott teljesítménnyel (minden alanynál az R^2 0,9 fölötti).

Az adatok feldolgozása során minden edzésen regisztráltuk az ismétlések átlagsebességét, ezzel kapva képet az edzésprogram előrehaladtával kialakuló hiperkompenzációról. Ezt követően kiszámoltuk a fejlődés ütemét is az egyes edzések átlagértékeire és az edzés alkalmak számértékére illesztett egyenes meredekségéből.

$\mathrm{Az}$ adatok feldolgozása STATISTICA 13.2 programcsomaggal történt. Normalitás vizsgálat után, a csoportokon belül az adatokat ismételt mérések variancia analízisével, a csoportok közötti különbségeket pedig Student független minták t-próbájával elemeztük.

\section{Eredmények}

A csoportok között az edzésidőszak alatt nem mutatkozott szignifikáns különbség a csoportok átlagsebességében. Mind a két csoport szignifikánsan nagyobb sebességgel tudta végezni a munkát az edzés időszak végén (2. ábra). Érdekes módon az edzések alatt produkált ismétlések átlagsebessége mintha tendenciózusan alacsonyabb értékeket venne fel az okklúziós csoportban.

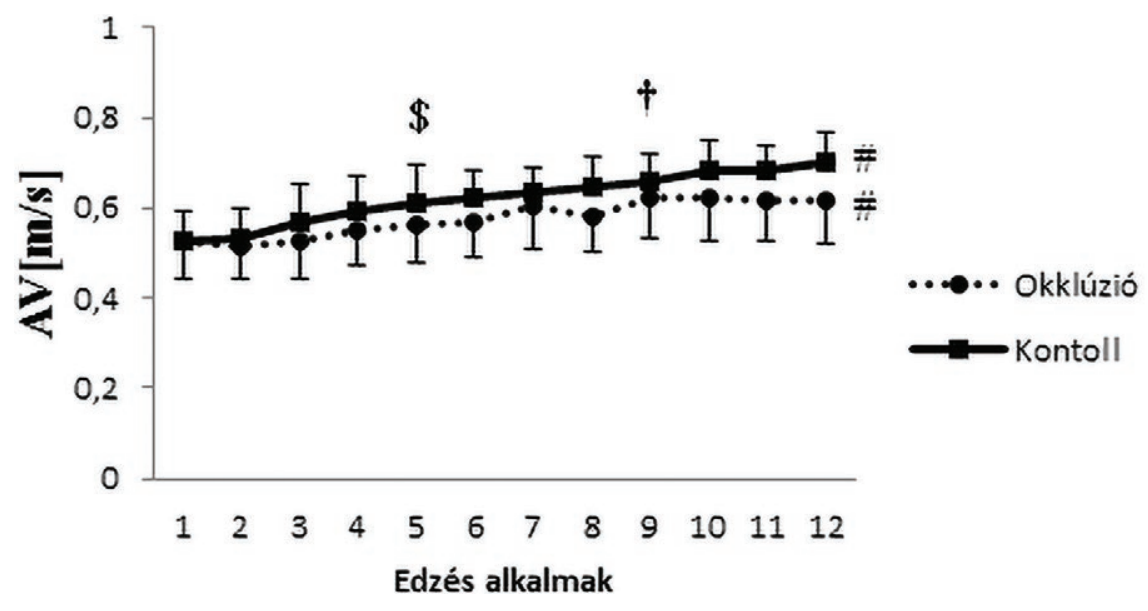

2. ábra Az edzések átlagsebesség változása. \$: első szignifikáns eltérés a kiindulási állapothoz viszonyítva a $\mathrm{K}$ csoportban $\mathrm{p}<0,05$, $\uparrow$ : első szignifikáns eltérés a kiindulási állapothoz viszonyítva az $\mathrm{O}$ csoportban $\mathrm{p}<0,05$, \#: szignifikáns eltérés a kezdet és a végállapot között $\mathrm{p}<0,05$ (az adatpontok az átlagértékeket és a szórásokat jelölik)

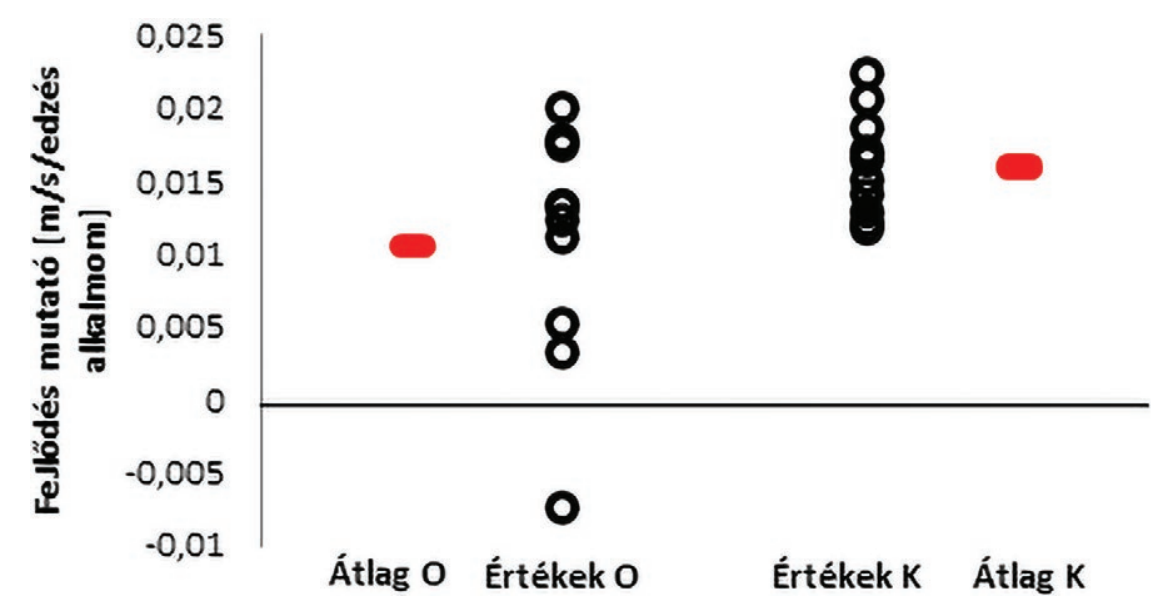

3. ábra Az átlagsebességek fejlődési meredeksége az edzésperiódusban (jelölések: a piros adatpont az átlagos értékeket jelölik csoporton belül, a fekete körök az egyéni fejlődésmutató értékek, O: okklúzió, K: kontroll) 
A $\mathrm{K}$ csoport átlagsebesség eredményei az 5 . edzés után mutattak szignifikáns növekedést a kiinduló értékhez képest, amíg ez az O csoportnál a 9. edzés után következett be (2. ábra).

A csoportok az átlagsebesség fejlödések meredekségében nem különböztek szignifikánsan egymástól (3. ábra). Az O csoportnál nagyobb a fejlődésmutató eredmények (3. ábra) szórása, mint a kontrol csoportnál. Az okklúziós csoportnál egy alany negatív fejlődési dinamikát mutatott.

Az alanyok az első hetekben kellemetlennek írták le az okklúziós terhelést, ám az utolsó két héten már nem jelentkezett senkinél sem diszkomfort érzet.

\section{Megbeszélés, következtetések}

Eredményeink szerint az edzések pihenőidejében alkalmazott okklúziós terhelés nem okoz szignifikáns átlagsebesség eltérést a nagy izomfeszüléssel járó guggoló edzéseken. Az okklúziós csoportnál viszont tendenciózusan alacsonyabb értékeket lehet látni, amely összefügghet az okklúzió által generált metabolikus stresszel. A fejlődések dinamikája nem mutatott szignifikáns különbséget a csoportok között, viszont az O csoport eredményeinek szórás és az egyik alany negatív fejlödés mutatója arra engedhet következtetni, hogy bizonyos esetekben erre az edzésterhelésre adott adaptációs mintázat eltérhet az elvárt trajektóriától. Eredményeink azt sugallják, hogy az általunk alkalmazott okklúziós edzés nem csökkenti számottevően a munkavégzés átlagsebesség értékét 1 hónapos krónikus edzésidőszak alatt. Az okklúziós csoportban viszont a szignifikáns fejlődés később jelenik meg. A rezisztencia edzés izomkontrakciós fázisa alatt a kontraháló izom fokozott energiahiányos állapotba kerül, melyből a sorozatok közti pihenőidőben tud regenerálódni. Az alkalmazott okklúziós terhelés pont ebbe a regenerálódási fázisba avatkozik be, valószínűleg lassítja a regeneráció folyamatát és hatást gyakorol a lokális metabolizmusra. Erről a megváltozott fiziológiás környezetről számos sejtbiológiai változást írtak le. Ezek közé tartozik a hipoxiás faktorok (Drummond és mtsai. 2008), növekedési faktorok (Pierce és mtsai 2006; Suga és mtsai. 2009) illetve a mitokondriális biogenezist támogató markerek emelkedése (Evans, Vance és Brown, 2010). Érdekes eredmény, hogy az élsportban is gyakran emlegetett növekedési hormon az IGF-1 (inzulinszerű növekedési faktor) fiziológiás emelkedését is leírták az okklúziós edzéssel összefüggésben (Takarada és és mtsai. 2000). Ezeken túl feltételezik az mTOR (mechanistic target of rapamycin) komplexhez köthetö, a fehérjeszintézist fokozó jelátviteli útvonalak aktiválódását (Manini és Clark 2009). Más kutatások azt demonstrálták, hogy okklúzió során a vénák falára fokozott nyíróerő hat (Takano és mtsai. 2005), mely nitrogén monoxidhoz kötött jelátviteli utakon keresztül, akár hozzájárulhat a bővebb kapillarizáció kialakulásához is (Hudlicka és Brown 2009).

Jelen vizsgálatunkban nem tudtunk kimutatni számottevő eltérést a kontrol- és az okklúziós csoport átlagsebesség és fejlődés mutató értékeik között az 1 hónapos edzésidőszak után. Az átlagsebesség értékek viszont a kontroll csoportnál előbb érték el a szignifikánsan emelkedett szintet, ha a csoportok kiindulási értékekeit vettük alapul. Adataink interpretálásánál meg kell említenünk, hogy esetünkben rendszeres fizikai aktivitást végző, jó fizikai állapotú fiatal felnőttekkel dolgoztunk, ám az okklúziós edzés hipertrofizáló és teljesítményfokozó hatásával foglakozó közlemények között többségben vannak az alacsony edzettségi szintű populáción folytatott vizsgálatok. Esetünkben limitáló tényezőként jelenik meg alacsony elemszám, így nem tudunk általános érvényü ajánlásokat megfogalmazni. A jövőben hasonló vizsgálatoknál érdemes lehet az elemszámot növelni, illetve olyan csoportokat is vizsgálni, ahol hosszabb a pihenőidő mind a sorozatok, mind az edzésalkalmak között.

Habár robosztus eltérések nem mutatatóak ki vizsgálatunkban, eredményeink mégis az edzésadaptáció egy nagyon fontos jelenségre hívják fel a figyelmet, mégpedig az individuális edzhetőség kérdésére. A fejlődés mutató nem minden esetben jelzett pozitív változást, a meredekségek pedig, főleg az okklúziós csoportnál, nagy szórást mutatnak. Az edzői gyakorlatban a maximális erő és az erőállóképesség más és más terhelési összetevők mentén, különböző edzéseszközök, gyakorlatok alkalmazásával kerülhet fejlesztésre. Az okklúziós edzés, egy olyan újfajta módszer lehet, mely a jövőben kombinálhatja ennek az említett két képességnek egy komplex módon történő fejlesztését. Az edzésadaptációs válaszok nagy individuális eltéréseket eredményezhetnek az olyan speciális edzéstechnikák esetén, mint amilyen az okklúziós terhelés. Az egyéni adaptációs válaszokat az alanyok vázizomzatának, kardiorespiratorikus 
rendszerének állapotán túl sejtélettani folyamatok határozzák meg, melyet fontos figyelembe venni az edzéstervezés folyamán is.

\section{Köszönetnyilvánítás}

A kutatási anyag az Emberi Erőforrások Minisztériuma ÚNKP-17-3 kódszámú Új Nemzeti Kiválósági Programjának Támogatásával készült.

\section{Referenciák}

1. Abe, T., Kearns, C.F., Sato, Y. (2006). Muscle size and strength are increased following walk training with restricted venous blood flow from the leg muscle, Kaatsu-walk training. J Appl Physiol (1985). 100, 1460-1466. doi. 10.1152/japplphysiol.01267.2005

2. American College of Sports Medicine position stand. Progression models in resistance training for healthy adults. Med Sci Sports Exerc. 2009. 41, 687-708

3. Drummond, M.J., Fujita, S., Abe, T., Dreyer, H.C., Volpi, E., Rasmussen, B.B. (2008). Human muscle gene expression following resistance exercise and blood flow restriction. Med Sci Sports Exerc. doi.10.1249/ MSS.0b013e318160ff84

4. Evans, C., Vance, S., Brown, M., (2010). Short-term resistance training with blood flow restriction enhances microvascular filtration capacity of human calf muscles. J Sports Sci. 28(9).999-1007. doi. 10.1080/02640414.2010.485647.

5. Hudlicka, O., Brown, M.D. (2009). Adaptation of skeletal muscle microvasculature to increased or decreased blood flow. role of shear stress, nitric oxide and vascular endothelial growth factor. J Vasc Res. 46, 504512 doi. $10.1159 / 000226127$

6. Loenneke, J.P., Fahs, C.A., Rossow, L.M., Sherk, V.D., Thiebaud, R.S., Abe, T., Bemben, D.A., Bemben, M.G. (2012). Effects of cuff width on arterial occlusion. implications for blood flow restricted exercise. European Journal of Applied Physiology. 112, 2903-2912. doi. 10.1007/s00421-011-2266-8

7. Loenneke, J.P., Young, K.C., Wilson, J.M., Andersen, J.C. (2013). Rehabilitation of an osteochondral fracture using blood flow restricted exercise. a case review. J Bodyw
Mov Ther. 17, 42-45. doi.10.1016/j. jbmt.2012.04.006

8. Luebbers, P.E., Fry, A.C., Kriley, LM,Butler, M.S. (2014). The effects of a 7-week practical blood flow restriction program on well-trained collegiate athletes. Journal of Strength and Conditioning Research. 28, 2270-2280. doi. 10.1519/JSC.0000000000000385

9. Manimmanakorn, A., Hamlin, M.J., Ross, J.J., Taylor, R., Manimmanakorn, N. (2013). Effects of low-load resistance training combined with blood flow restriction or hypoxia on muscle function and performance in netball athletes. J Sci Med Sport. 16, $337-$ 342. doi. 10.1016/j.jsams.2012.08.009

10. Manini T.M., Clark B.C. (2009). Blood flow restricted exercise and skeletal muscle health. Exerc Sport Sci Rev. 37(2).78-85. doi. 10.1097/JES.0b013e31819c2e5c

11. Pierce, J.R., Clark, B.C., Ploutz-Snyder, L.L.,Kanaley, J.A. (2006). Growth hormone and muscle function responses to skeletal muscle ischemia. J Appl Physiol (1985). 101, 1588159. doi.10.1152/japplphysiol.00585.2006

12. Richens B., Cleather, D.J. (2014). The relationship between the number of repetitions peformed at given intensities is different in endurance and strenngth trained athletes. Bilogy of Sport. 31(2). 157-161. doi. 10.5604/20831862.1099047

13. Scott B.R., Loenneke J.P., Slattery K.M., Dascombe B.J. (2016). Blood flow restricted exercise for athletes. A review of available evidence. Journal of Science and Medicine in Sport. 19(5).360-7. doi. 10.1016/j. jsams.2015.04.014.

14. Suga, T., Okita, K., Morita, N., Yokota, T., Hirabayashi, K., Horiuchi, M., Takada, S., Takahashi, T., Omokawa, M., Kinugawa, S., Tsutsui, H. (2009). Intramuscular metabolism during low-intensity resistance exercise with blood flow restriction. J Appl Physiol (1985) 106, 1119-1124. doi. 10.1152/ jappl.2000.88.1.61

15. Takano, H., Morita, T., Iida, H., Asada, K., Kato, M., Uno, K., Hirose, K., Matsumoto, A., Takenaka, K., Hirata, Y., Eto, F., Nagai, R., Sato, Y,Nakajima, T. (2005). Hemodynamic and hormonal responses to a short-term lowintensity resistance exercise with the reduction 
of muscle blood flow. European Journal of Applied Physiology. 95, 65-73 doi. 10.1007/ s00421-005-1389-1

16. Takarada, Y, Nakamura, Y, Aruga, S, Onda, T, Miyazaki, S,Ishii, N. (2000) Rapid increase in plasma growth hormone after low-intensity resistance exercise with vascular occlusion. J Appl Physiol (1985). 88, 61-65. doi. 10.1152/ jappl.2000.88.1.61

17. Takarada, Y, Sato, Y,Ishii, N. (2002). Effects of resistance exercise combined with vascular occlusion on muscle function in athletes. European Journal of Applied Physiology. 86, 308-314.

18. Wernbom M., Augustsson J., Raastad T. (2008) Ischemic strength training. a lowload alternative to heavy resistance exercise? Scand J Med Sci Sports. 18(4).401-16. doi. $10.1111 / \mathrm{j} .1600-0838$
19. Yamanaka, T., Farley, R.S.,Caputo, J.L. (2012). Occlusion training increases muscular strength in division IA football players. Journal of Strength and Conditioning Research. 26, 2523-2529. doi. 10.1519/ JSC.0b013e31823f2b0e

20. Yasuda, T., Fukumura, K., Fukuda, T., Uchida, Y., Iida, H., Meguro, M., Sato, Y., Yamasoba, T.,Nakajima, T. (2014). Muscle size and arterial stiffness after blood flow-restricted low-intensity resistance training in older adults. Scand J Med Sci Sports. 24, 799-806. doi. $10.1111 /$ sms.12087 